Fakultas Hukum Universitas Lancang Kuning, Jalan Yos Sudarso KM 8 Rumbai Pekanbaru, Riau,

Kode Pos 28266. Telp: (+62761)-51877

E-mail: jurnal.respublica@ac.id

Website: https://journal.unilak.ac.id/index.php/Respublica

\title{
PENYALAHGUNAAN WEWENANG JABATAN OLEH PEJABAT NEGARA/PEMERINTAH : PERSPEKTIF HUKUM ADMINISTRASI NEGARA DAN HUKUM PIDANA
}

\author{
Shobirin \\ ${ }^{a}$ Dosen Fakultas Hukum Universitas Ahmad Dahlan, Yogyakarta, Email: sobirin.malian@law.uad.ac.id
}

\section{Article Info}

\section{Article History:}

Received : 13-08-2020

Revised : 20-09-2020

Accepted : 13-10-2020

Published : 30-11-2020

\section{Keywords:}

Abuse of Power

State Official

Law

\begin{abstract}
Abuse of power is as old as the age of human civilization. Abuse of power is an unlawful act done by a person or people in an official capacity. Abuse of power breaks the article 3 of the Indonesian Law No. 31 Year 1999 jo the Indonesian Law No. 20 Year 2001, that is "Anybody who with the intention to earn profit for himself or another person or a corporation, abuses the authority, opportunity or facilities given to him on account of his post or position which may cause loss to the state finance or state economy, shall be sentenced to life imprisonment or a minimum sentence of 1 (one) year and a maximum of 20 (twenty years) or a minimum fine of ..." It is a qualitative research methodology with observation and literary review to collect data. The research concludes that state administration officials should have professionally technical skills and morality to do their duties. If they do not have them, they might be fired in the perspective of administrative law and be sentenced to life imprisonment in the perspective of criminal law.
\end{abstract}

\begin{abstract}
Abstrak
Penyalahgunaan wewenang jabatan bisa jadi sudah sama tuanya dengan peradaban manusia. Pada umumnya penyalahgunaan wewenang jabatan adalah pemanfaatan kesempatan oleh seseorang atau sekelompok orang yang tengah menjabat dengan mengambil kesempatan karena jabatannya itu. Penyalahgunaan wewenang jabatan melanggar Pasal 3 UU Nomor 31 Tahun 1999 jo UU Nomor 20 Tahun 2001, intinya..." jika seseorang atau kelompok mengambil keuntungkan diri sendiri atau orang lain atau suatu korporasi, menyalahgunakan kewenangan, kesempatan atau sarana yang ada padanya karena jabatan dan merugikan keuangan negara atau perekonomian negara negara dipidana dengan pidana penjara seumur hidup atau pidana penjara paling singkat satu tahun dan paling lama dua puluh tahun dan denda..." Penelitian ini menggunakan metode kualitatif dengan teknik pengumpulan data dilakukan dengan observasi (pengamatan) dan didukung studi kepustakaan. Hasil studi menunjukkan, bahwa pejabat administrasi negara dalam melakukan tugasnya di samping harus memiliki kemampuan teknis professional, juga harus memiliki moral (etika) yang tinggi. Jika kemampuan itu tidak dimiliki, maka dia dapat terkena hukuman pemecatan sebagai pejabat administratif dalam perspektif HAN (hukum administrasi negara) dan dapat dikenai sanksi pidana dalam perspektif hukum pidana.
\end{abstract}




\section{PENDAHULUAN}

Penyalahgunaan wewenang jabatan bisa jadi sudah sama tuanya dengan peradaban manusia. Pada umumnya penyalahgunaan wewenang jabatan adalah pemanfaatan kesempatan oleh seseorang atau sekelompok orang yang tengah menjabat dengan mengambil kesempatan karena jabatannya itu. Penyalahgunaan wewenang jabatan melanggar Pasal 3 UU Nomor 31 Tahun 1999 jo UU Nomor 20 Tahun 2001, intinya..." jika seseorang atau kelompok mengambil keuntungkan diri sendiri atau orang lain atau suatu korporasi, menyalahgunakan kewenangan, kesempatan atau sarana yang ada padanya karena jabatan dan merugikan keuangan negara atau perekonomian negara negara dipidana dengan pidana penjara seumur hidup atau pidana penjara paling singkat satu tahun dan paling lama dua puluh tahun dan denda..." Penelitian ini menggunakan metode kualitatif dengan teknik pengumpulan data dilakukan dengan observasi (pengamatan) dan didukung studi kepustakaan. Hasil studi menunjukkan, bahwa pejabat administrasi negara dalam melakukan tugasnya di samping harus memiliki kemampuan teknis professional, juga harus memiliki moral (etika) yang tinggi. Jika kemampuan itu tidak dimiliki, maka dia dapat terkena hukuman pemecatan sebagai pejabat administratif dalam perspektif HAN (hukum administrasi negara) dan dapat dikenai sanksi pidana dalam perspektif hukum pidana.

Faktanya pada 17 November 2019 lalu, beredar berita Direktur Garuda Indonesia menyelundupkan onderdil motor mewah. Direktur Garuda Indonesia, I Gusti Ngurah Askhara atau Ari Askhara menyelundupkan onderdil motor gede (moge) Harley Davidson dan Brompton yang berakhir dengan pemecatannya sebagai Direktur Utama Garuda Indonesia itu. Penemuan barang mewah oleh petugas Bea dan Cukai di lambung pesawat Garuda dengan nomor penerbangan GA 9721 bertipe Airbus A330-900 Neo terjadi pada Minggu (17 November 2019) itu menambah panjangnya catatan tentang penyalahgunaan wewenang ( $a$ buse of power) oleh seorang pejabat negara, sekaligus membuktikan bahwa sebuah jabatan itu sangat rentan disimpangi.

Dampak terhadap penyelundupan tersebut, menurut Menteri Keuangan Sri Mulyani Indrawati, negara dirugikan antara Rp 532 juta hingga Rp 1,5 milyar. ${ }^{1}$ Sebagai "komitmen" pemerintah mewujudkan good clean governance dan good government Dewan Komisaris PT Garuda Indonesia Persero Tbk. hari itu (9 Desember 2019) resmi memberhentikan empat direktur yang ditengarai terlibat kasus penyelundupan barang gelap tersebut. Keempatnya

\footnotetext{
${ }^{1}$ Koran Tempo, 19 November 2019.
} 
adalah Direktur Kargo dan Pengembangan Usaha Mohammad Iqbal, Direktur Operasi Bambang Adisurya Angkasa, Direktur Human Capital Heri Akhyar, serta Direktur Teknik dan Layanan Iwan Joeniarto.

Pernyataan pada jumpa pers, 9 Desember $2019,{ }^{2}$ Ketua Dewan Komisaris Garuda Sahala Lumban Gaol, menyatakan, "Dewan Komisaris Garuda Indonesia sesuai kewenangan dalam Anggaran Dasar Perseroan telah menerbitkan Surat Keputusan Dewan Komisaris Garuda Indonesia tentang pemberhentian anggota-anggota Direksi Garuda Indonesia.” Di samping memberhentikan empat direksi itu, Dewan Komisaris Garuda telah mengangkat Fuad Rizal sebagai pelaksana tugas Direktur Operasi serta Pelaksana tugas Direktur Teknik dan Layanan menggantikan Iwan Joeniarto dan Bambang.

Setelah diusut pihak Polri dan tim Garuda, benda-benda ini telah dipalsukan dokumennya sebagai pemilik penumpang, padahal benda-benda itu ternyata milik Direktur Utama Garuda, Ari Askhara. Pada 5 Desember 2019 Menteri BUMN Erick Thohir telah memberhentikan Ari Askhara dari jabatannya secara tidak hormat. ${ }^{3}$

Kasus lain penyalahgunaan wewenang yang menghebohkan adalah dicopot dan ditahannya Brigjen Polisi Prasetijo sebagai Kepala Biro Koordinasi dan Pengawasan Penyidik Pegawai Negeri Sipil (Karo Korwas dan PPNS) Badan Reserse Kriminal (Bareskrim) Polri, ${ }^{4}$ karena mengeluarkan dari penyelidikan internal Polri ditemukan Brigjen Prasetijo diketahui mengeluarkan surat jalan bagi Djoko Tjandra, terdakwa (buron) koruptor kelas kakap.

Berdasarkan kasus di atas, terbukti sebuah jabatan yang memiliki kewenangan besar apalagi strategis, sangat rentan terjadi penyalahgunaan wewenang (a buse of power). Oleh karena itu, pernyataan sejarawan Inggris, John Emerich Edward Dalberg Acton atau lebih dikenal dengan Lord Acton (1833-1902) masih sangat relevan hingga saat ini. Pernyataannya kala itu berbunyi, "Power tends to corrupt. Absolute power corrupts absolutely" ("Kekuasaan itu cenderung korup. Kekuasaan absolut korup seratus persen.”).

Negara hukum Pancasila seperti di Indonesia, hukum sejatinya ditempatkan sebagai aturan main pokok dalam penyelenggaraan pemerintahan, kenegaraan dan kemasyarakatan. Hal ini tujuannya agar tercipta kegiatan pemerintahan, kenegaraan dan kemasyarakatan yang bersih, adil, makmur, damai, dan sejahtera.

\footnotetext{
${ }^{2}$ Republika, 9 Desember 2019.

${ }^{3}$ Kompas, 6 Desember 2019

${ }^{4}$ Kompas, 16 Juli 2020
} 
Kegiatan administrasi negara yang dilakukan oleh pejabat pemerintahan pun dalam pelaksanaannya dipayungi oleh Undang-Undang Nomor 30 Tahun 2014 tentang Administrasi Negara, Undang-Undang Nomor 28 Tahun 1999 tentang Penyelenggara Negara yang Bersih dan Bebas dari Korupsi, Kolusi dan Nepotisme dan asas-asas umum pemerintahan yang baik. Hal ini agar tidak terjadi penyalahgunaan kekuasaan/wewenang yang dimiliki terhadap kepentingan umum.

Kenyataannya kasus penyalahgunaan wewenang para pejabat masih saja terjadi, hal ini sering membuat orang awam menjadi bingung dan bertanya-tanya terutama yang belum paham hukum administrasi negara dan hukum pidana. Berdasarkan pemapaparan di atas maka peneliti tertarik untuk mengkaji tentang apakah tindakan tersebut perbolehkan oleh hukum; dan apakah dasar hukum tindakan tersebut; serta bagaimana sanksi atas penyalahgunaan wewenang itu.

Tulisan ini menggunakan jenis penelitian yuridis normatif, yaitu meneliti kaidah hukum (peraturan perundang-undangan, yurisprudensi, atau hukum tidak tertulis lainnya) dan asas-asas hukum. ${ }^{5}$ Penelitian hukum digunakan untuk menghasilkan argumentasi, teori atau konsep baru sebagai preskripsi dalam menyelesaikan masalah yang dihadapi. Karena pada keilmuan yang bersifat deskriptif jawaban yang diharapkan adalah true atau false. Sedangkan jawaban yang diharapkan dalam penelitian hukum adalah right, appropriate, inappropriate, atau wrong. Dengan demikian dapat dikatakan bahwa hasil yang diperoleh di dalam penelitian hukum sudah mengandung nilai. ${ }^{6}$

Untuk menunjang jenis penelitian ini, maka digunakan metode pendekatan undangundang (statute approach) untuk menelaah dari aspek pengaturan administrasi dalam tindak pidana korupsi. ${ }^{7}$ Pengaturan tentang penyalahgunaan wewenang sebagaimana diatur dalam Pasal 3 Undang-undang Tipikor sebagaimana diulas di dalam penelitian ini memiliki perbedaan redaksional dengan pengaturan yang terdapat dalam kajian hukum administrasi sebagaimana dalam Pasal 21 Undang-undang Nomor 30 Tahun 2014 yang menggunakan istilah penyalahgunaan wewenang.

\footnotetext{
5 Bagir Manan, Penelitian Bidang Hukum, Bandung: Jurnal Hukum, Puslitbangkum Unpad, Perdana, Januari, (1999): 4.

${ }^{6}$ Marzuki, Peter Mahmud, Penelitian Hukum, (Jakarta: Kencana Prenada Media Group, 2005), 13.

${ }^{7}$ Maroni, Kriminalisasi Di Luar KUHP dan Implikasinya Terhadap Hukum Acara Pidana, Dalam Buku Studi Penegakan dan Pengembangan Hukum. (Bandar Lampung: Penerbit Unila. 2013), 104.
} 


\section{PERSPEKTIF HUKUM ADMINISTRASI NEGARA}

A buse of (power) atau "Penyalahgunaan wewenang" dan "menyalahgunakan kewenangan" merupakan istilah yang lahir dari doktrin Hukum Administrasi Negara dan nampaknya "core" ranah hukum tersebut. Secara etimologis, istilah "penyalahgunaan" dan "menyalahgunakan" berasal dari dua suku kata "salah-guna". Penyalahgunaan yang berbentuk noun berarti proses, cara, perbuatan menyalahgunakan; penyelewengan, sedangkan "menyalahgunakan" yang berbentuk verb dimaknai melakukan sesuatu tidak sebagaimana mestinya; menyelewengkan. ${ }^{8}$ Istilah penyalahgunaan/menyalahgunakan dalam istilah Belanda dikenal dengan misbruik yang memiliki kemiripan dengan istilah missbrauch dalam bahasa Jerman atau misuse dan abuse dalam istilah bahasa Inggris yang maknanya selalu diasosiasikan dengan hal yang bersifat negatif yaitu penyelewenangan. Akhir-akhir ini terminologi yang lebih halus yaitu dagang pengaruh/trading in influence. Jadi antara istilah "penyalahgunaan" dan "menyalahgunakan" tidak ada perbedaan,"penyalahgunaan" menunjuk pada proses, cara, perbuatannya, sedangkan "menyalahgunakan" menunjuk pada tindakan atau pelaksanaanya. Sementara itu, istilah "wewenang" dan "kewenangan" berasal dari kata "wenang" keduanya berbentuk noun. ${ }^{9}$ Wewenang dimaknai Hak dan kekuasaan untuk bertindak; kewenangan. Sedangkan kewenangan berarti (1). Hal berwenang; (2). Hak dan kekuasaan yang dipunyai untuk melakukan sesuatu. Dalam bahasa Inggris dikenal dengan "authority" dan tidak ada pembedaan antara keduanya, sama halnya dengan istilah dalam bahasa Belanda, yang tidak membedakan keduanya. Istilah yang sering digunakan adalah bevoegdheid, meskipun ada istilah lain yang terjemahannya adalah kewenangan atau kompetensi yaitu bekwaamheid. ${ }^{10}$

Secara terminologis, antara istilah "wewenang" dengan "kewenangan" tidak ada perbedaan substansial. Istilah wewenang dan kewenangan selalu dikaitkan dengan "hak dan kekuasaan untuk bertindak atau melakukan sesuatu". Jadi pembedaan yang dilakukan terhadap konsepsi "menyalahgunakan kewenangan" dan "penyalahgunaan wewenang" dengan argumentasi adanya perbedaan pengertian atau definisi yuridis antara "kewenangan" dan "wewenang" menjadi tidak lagi relevan. ${ }^{11}$

\footnotetext{
${ }^{8}$ WJS Poerwadarminta, Kamus Besar Bahasa Indonesia, (Jakarta: Balai Pustaka, 1976), 1150.

${ }^{9}$ BP2B, Kemendikbud, KKBI, Daring, kbbi.web.id/wenang, diakses tanggal 6 September 2020.

${ }^{10}$ Susi Moeimam dan Steinhauer, Hein, Kamus Belanda-Indonesia, (Jakarta: Gramedia Pustaka, 2005), 100.

11 Andhi Nirwanto, Dikotomi Terminologi Keuangan Negara dalam Perspektif Tindak Pidana Korupsi, (Semarang: Aneka Ilmu, Cetakan Pertama, 2014), 16-19.
} 


\section{KONSEP PENYELAHGUNAAN WEWENANG}

Penyalahgunaan wewenang dalam konsep hukum administrasi negara, selalu diparalelkan dengan konsep detournament de pouvoir dalam sistem hukum Prancis atau abuse of power/misuse of power dalam istilah bahasa Inggris. ${ }^{12}$ Secara historis, konsep "detournament de pouvoir" pertama kali muncul di Prancis dan merupakan dasar pengujian lembaga Peradilan Administrasi Negara terhadap tindakan pemerintahan dan dianggap sebagai asas hukum yang merupakan bagian dari "de principes generaux du droit". Conseil d'Etat adalah lembaga peradilan pertama yang menggunakannya sebagai alat uji, yang kemudian diikuti oleh negara-negara lain. Pejabat pemerintahan dinyatakan melanggar prinsip détournement de pouvoir, manakala tujuan dari keputusan yang dikeluarkan atau tindakan yang dilakukan bukan untuk kepentingan atau ketertiban umum tetapi untuk kepentingan pribadi si pejabat (termasuk keluarga atau sekutunya). ${ }^{13}$

Jika diperhatikan konsep "détournement de pouvoir" oleh Conseil d'Etat Prancis telah dikembangkan menjadi tiga kategori, ${ }^{14}$ yaitu:

a. when the administrative act is completely taken without the public interest in mind;

b. when the administrative act is taken on the basis of the public interest but the discretion which the administration exercises in doing so was not conferred by law for that purpose;

c. in cases of détournement de procedure where the administration, concealing the real content of the act under a false appearance, follows a procedure reserved by law for other purposes.

Konsep "détournement de pouvoir" yang lahir dan berkembang di Prancis ini kemudian membawa pengaruh pada penegakan hukum di negara Eropa lain seperti di Belanda sebagai salah satu negara eks jajahan Prancis dan Indonesia sebagai negara eks jajahan Belanda. Penyalahgunaan wewenang oleh Hoge Raad dijadikan sebagai dasar pertimbangan hukum dalam membuat Putusan. Sementara di Indonesia, penyalahgunaan wewenang dijadikan alasan (dasar) gugatan bagi seseorang atau badan hukum perdata yang merasa kepentingannya dirugikan oleh suatu Keputusan TUN (pihak Penggugat). ${ }^{15}$

\footnotetext{
${ }^{12}$ Philiphus M. Hadjon, dkk, Hukum Admnistrasi dan Good Governace, (Jakarta: Penerbit Universitas Trisakti, Cetakan Kedua, 2012), 21-22

13 Yulius, Perkembangan Pemikiran dan Pengaturan Penyalahgunaan Wewenang di Indonesia (Tinjauan Singkat Dari Perspektif Hukum Administrasi Negara Pasca Berlakunya Undang-Undang Nomor 30 Tahun 2014), Artikel dalam Jurnal Hukum dan Peradilan, Badan Penelitian dan Pengembangan Hukum dan Peradilan Mahkamah Agung RI, Volume 04 Nomor 3 November 2015. h. 364.

${ }^{14}$ Ibid., hlm. 365.

${ }^{15}$ Pasal 53 ayat (2) huruf b UU Nomor 5 Tahun 1986 tentang Peradilan TUN.
} 
Verklarend Woordenboek Openbaar Bestuur merumuskan "penyalahgunaan wewenang" sebagai penggunaan wewenang tidak sebagaimana mestinya. Dalam hal ini, pejabat dianggap melanggar asas spesialitas (asas tujuan) karena yang bersangkutan menggunakan wewenangnya untuk tujuan yang menyimpang dari tujuan yang telah diberikan kepada wewenang tersebut. ${ }^{16}$

Asas spesialitas ini dahulu pernah diterapkan dalam hukum positif Indonesia, yaitu dalam Pasal 53 ayat (2) huruf b UU Nomor 5 Tahun 1986 tentang Peradilan Administrasi, berkenaan dengan alasan-alasan untuk mengajukan gugatan ke Peradilan Administrasi. Pada bagian penjelasannya, ketentuan ini dinyatakan secara tegas sebagai "penyalahgunaan wewenang", walaupun kemudian ketentuan ini dihapus dan diganti dengan AUPB pada saat dilakukan perubahan terhadap undang-undang dimaksud. ${ }^{17}$

Ketentuan ini dalam praktek hukum pidana, khususnya pada Peradilan Tipikor seringkali digunakan untuk menjelaskan unsur "menyalahgunakan kewenangan" yang terdapat dalam ketentuan Pasal 3 UU Pemberantasan Tipikor melalui penafsiran ekstensif dengan pendekatan doktrin otonomi hukum pidana. ${ }^{18}$

Terjadinya penyalahgunaan wewenang perlu diukur dengan membuktikan secara faktual bahwa seorang pejabat telah menggunakan wewenangnya untuk tujuan lain atau tidak. Harus dapat dibuktikan juga bahwa terjadinya penyalahgunaan wewenang dilakukan secara sadar dengan mengalihkan tujuan yang telah diberikan kepada wewenang itu (bukan karena kealpaan). Pengalihan tujuan tersebut didasarkan atas interest pribadi, baik untuk kepentingan dirinya sendiri ataupun untuk orang lain. ${ }^{19}$

Secara yuridis, penyalahgunaan wewenang dalam UU Administrasi Pemerintahan dinyatakan terjadi ketika "badan dan/atau pejabat pemerintahan (Pasal 18 ayat (2) UU Administrasi Pemerintahan) dalam membuat keputusan dan/atau melakukan tindakan

\footnotetext{
${ }^{16}$ Arfan Faiz, Muhlizi, Reformulasi Diskresi Dalam Penataan Hukum Administrasi, Artikel dalam Jurnal Rechts Vinding, Volume 1 Nomor 1 Januari-April 2012.Hlm.94. Lihat juga, Hadjon, Philipus M., dkk, Hukum Administrasi dan Good Governance, (Jakarta: Penerbit Universitas Trisakti, Cetakan Kedua, 2012), 21-22.

${ }_{17}$ Tri Cahya Indra Permana, Hak Permohonan Pejabat/Badan Atas Dugaan Penyalahgunaan Wewenang: Bunga Rampai Peradilan Administrasi Kontemporer, Editor Subur, dkk., (Yogyakarta: Genta Press, 2014), 5152.

18 Putusan Mahkamah Agung Republik Indonesia (MARI) Nomor: 14/Pid.Sus /2012/PN.AB. dengan Terdakwa Edi Tri Sukmono, SH. Alias Edi dan Putusan MARI Nomor: 03/PID.SUS/TPK/2013/PN.PBR. dengan Terdakwa Amril Daud.

${ }^{19}$ Abdul Latif, Hukum Administrasi Dalam Tindak Pidana Korupsi, (Jakarta: Prenada Media Group, 2014 ), 35.
} 
melampaui wewenang, mencampuradukkan wewenang, dan/atau bertindak sewenangwenang. $" 20$

Badan dan/atau Pejabat Pemerintahan melampaui wewenang ketika keputusan dan/atau tindakan yang dilakukan dengan a). melampaui masa jabatan atau batas waktu berlakunya wewenang; b). melampaui batas wilayah berlakunyawewenang; dan/atau c). bertentangan dengan ketentuan peraturan perundang-undangan." ${ }^{21}$ Sedangkan keputusan dan/atau tindakan Badan dan/atau Pejabat Pemerintahan dikategorikan mencampuradukkan wewenang apabila dilakukan diluar cakupan bidang atau materi wewenang yang diberikan dan/atau bertentangan dengan tujuan wewenang yang diberikan." 22 Terakhir Badan dan/atau Pejabat Pemerintahan dinyatakan sewenang-wenang manakala keputusan dan/atau tindakannya dilakukan tanpa dasar kewenangan dan/atau bertentangan dengan Putusan Pengadilan yang berkekuatan hukum tetap.",23

Undang-Undang Administrasi Pemerintahan tidak menjelaskan definisi, pengertian, maupun konsep penyalahgunaan wewenang. Pasal 17 Undang-Undang No. 30 Tahun 2014 tentang Administrasi Pemerintahan hanya mengatur tentang larangan penyalahgunaan wewenang dan tiga spesies larangan penyalahgunaan wewenang, yang meliputi larangan melampaui wewenang, larangan mencampuradukkan wewenang dan larangan bertindak sewenang-wenang, yang secara konseptual dan teoritis menurut ahli Hukum Administrasi Negara dan praktisi Hukum Administrasi Negara (hakim PTUN) tidak tepat dan cenderung mengaburkan. $^{24}$

Perluasan makna penyalahgunaan wewenang dalam Undang-Undang Administrasi Pemerintahan dan perdebatan yang menyertainya tidak boleh menghalangi keberlakuan norma penyalahgunaan wewenang dalam undang-undang dimaksud, karena sebagai undangundang yang dibentuk oleh lembaga yang berwenang yaitu legislatif, maka sesuai dengan asas legalitas undang-undang tersebut mengikat secara umum dan harus dilaksanakan serta tidak dapat disimpangi sebelum dicabut atau dibatalkan oleh lembaga negara yang berwenang. ${ }^{25}$

\footnotetext{
${ }^{20}$ Pasal 17 UU No. 30 Tahun 2014 tentang Administrasi Pemerintahan.

21 Pasal 18 UU No. 30 Tahun 2014 tentang Administrasi Pemerintahan.

${ }^{22}$ Pasal 18 ayat (2) UU No. 30 Tahun 2014 tentang Administrasi Pemerintahan.

${ }^{23}$ Pasal 18 ayat (3) UU No. 30 Tahun 2014 tentang Administrasi Pemerintahan.

${ }^{24}$ Hadjon, Philipus M., Peradilan Tata Usaha Negara Dalam Konteks Undang-Undang Nomor 30 Th. 2014, Makalah, disampaikan dalam Colloqium Membedah Undang-Undang Nomor 30 Tahun 2014 tentang Administrasi Pemerintahan, 5 Juni 2015, Garden Palace Surabaya. Hlm. 11.

${ }^{25}$ Yulius: Op-cit., 377.
} 


\section{KONSEP MENYALAHGUNAKAN KEWENANGAN}

Menyalahgunakan kewenangan merupakan istilah yang identik dengan ranah hukum pidana, khususnya dalam praktek peradilan pidana ketika berbicara tentang Tipikor yang berkaitan dengan jabatan publik atau jabatan pemerintahan. Hal ini tidak lain karena "menyalahgunakan kewenangan" merupakan salah satu unsur penting dalam Tipikor yang berkaitan dengan jabatan bahkan merupakan bestanddeel delict. ${ }^{26}$ Menyalahgunakan kewenangan sebagai salah satu unsur dalam dalam terbentuknya delik Sadjijono, ${ }^{27}$ merupakan species delict dari unsur melawan hukum sebagai genus delict. Menyalahgunakan kewenangan dalam konteks ini akan selalu berkaitan dengan jabatan pejabat publik, bukan dalam kaitan dan pemahaman jabatan dalam ranah struktur keperdataan. Namun demikian, istilah "menyalahgunakan kewenangan" seperti halnya "penyalahgunaan wewenang" sebenarnya merupakan istilah yang lahir dalam rumpun Hukum Administrasi Negara, bahkan istilah tersebut merupakan salah satu asas dalam AUPB, yaitu asas tidak menyalahgunakan kewenangan. ${ }^{28}$

Unsur "menyalahgunakan kewenangan" dalam Tipikor dapat ditemukan dalam rumusan Pasal 3 UU Pemberantasan Tipikor, yang selalu dikaitkan dengan jabatan yang dimiliki seseorang pejabat publik (menyalahgunakan kewenangan karena jabatan), yang rumusannya sebagai berikut:

"Setiap orang yang dengan tujuan menguntungkan diri sendiri atau orang lain atau suatu korporasi, menyalahgunakan kewenangan, kesempatan atau sarana yang ada padanya karena jabatan atau kedudukan yang dapat merugikan keuangan negara atau perekonomian negara, dipidana dengan ... rupiah)."

Subjek hukum dalam tindak pidana ini adalah setiap orang yang berarti orang perseorangan atau termasuk korporasi. ${ }^{29}$ Akan tetapi karena korporasi sebagai rechtsperson tidak mungkin memiliki jabatan atau kedudukan seperti natuurlijke person, maka Tipikor yang terdapat dalam ketentuan Pasal 3 tersebut hanya dapat dilakukan oleh orang perseorangan yaitu aparatur negara atau pejabat publik. $^{30}$

\footnotetext{
${ }^{26}$ Putusan Mahkamah Agung RI Nomor 1485K/Pid.Sus/2013, tanggal 2 Oktober 2013, hlm. 132.

${ }^{27}$ Dalam Jurnal PERSPEKTIF Volume X No. 4 Tahun 2005 Edisi Oktober, hlm. 16-18. Lihat lebih lengkap, Shinta Agustina, dkk, Penjelasan Hukum: Sifat Melawan Hukum Dalam Kasus Korupsi, (Jakarta: LeIP, 2016), 61-70.

${ }^{28}$ Pasal 1 angka 3 UU No. 20 Tahun 2001 tentang Pemberantasan Tipikor

${ }^{29}$ Ibid

${ }^{30}$ Wiyono, R., Pembahasan Undang-Undang Pemberantasan Tindak Pidana Korupsi, Edisi Kedua, (Jakarta: Sinar Grafika, 2012), 45. Lihat juga Adami Chazawi, Hukum Pidana Materiil dan Formil Korupsi di Indonesia, (Malang: Bayumedia, 2005), 49.
} 
Kewenangan yang dimaksud dalam Pasal 3 UU Pemberantasan Tipikor merupakan kewenangan dari Pegawai Negeri sebagaimana dimaksud dalam ketentuan Pasal 1 angka 2 huruf a, huruf b, huruf c, huruf $d$, dan huruf e UU Pemberantasan Tipikor, yang pengertiannya lebih luas dari pengertian kewenangan menurut konsep Hukum Tata Negara atau Hukum Tata Usaha Negara yang hanya terbatas pada ketentuan Pasal 1 angka 2 huruf a, huruf $b$, huruf c, dan huruf e UU Pemberantasan Tipikor. ${ }^{31}$

Secara yuridis, mengenai menyalahgunakan kewenangan karena jabatan, UU Pemberantasan Tipikor tidak memberikan definisi atau pengertian tersendiri. Istilah "menyalahgunakan kewenangan" justru ditemukan dalam UU No.30 Tahun 2014 tentang Administrasi Pemerintahan yaitu sebagai bagian dari Asas-asas Umum Pemerintahan yang Baik (AUPB), yang di antara berupa "asas tidak menyalahgunakan kewenangan". 32

Jika dicermati, bentuk-bentuk atau jenis perbuatan yang dikategorikan sebagai tindakan menyalahgunakan kewenangan sebagaimana disebutkan dalam penjelasan asas “tidak menyalahgunakan kewenangan", maka bentuk-bentuk atau jenis perbuatan tersebut sama dengan bentuk dan jenis keputusan dan/atau tindakan yang dikategorikan sebagai larangan penyalahgunaan wewenang. Bahkan rincian dalam larangan penyalahgunaan wewenang lebih lengkap dan ada yang tidak tercakup dalam penjelasan asas "tidak menyalahgunakan kewenangan". Namun yang pasti dalam penjelasan asas tersebut, unsur penyimpangan tujuan (asas spesialitas) yang dalam Hukum Administrasi Negara selama ini selalu diidentikkan dengan pengertian "penyalahgunaan wewenang",juga dimasukkan dalam penjelasan asas "tidak menyalahgunakan kewenangan".

Larangan bagi Pejabat Administrasi Pemerintahan untuk "tidak menyalahgunakan kewenangan" dalam menetapkan dan/atau melakukan keputusan dan/atau tindakan juga terdapat dalam Pasal 8 ayat (3) UU Administrasi Pemerintahan. Sayangnya, dalam undangundang ini tidak diatur mengenai sanksi apabila terjadi pelanggaran atas ketentuan tersebut. Adami Chazawi mendefinisikan, "menyalahgunakan kewenangan" sebagai perbuatan yang dilakukan oleh orang yang sebenarnya berhak untuk melakukannya, tetapi dilakukan secara salah atau diarahkan pada hal yang salah dan bertentangan dengan hukum atau kebiasaan. Perbuatan "menyalahgunakan kewenangan" hanya mungkin terjadi apabila terpenuhi dua syarat, yaitu: a) si pembuat yang menyalahgunakan kewenangan berdasarkan kedudukan atau

\footnotetext{
${ }^{31}$ Putusan Mahkamah Agung RI Nomor 2357K/Pid.Sus/2015, tanggal 4 November 2015, hlm. 62-62.

32 Pasal 10 ayat (1) huruf e UU No. 30 Tahun 2014 tentang Administrasi Pemerintahan.
} 
jabatan tertentu memang mempunyai kewenangan yang dimaksudkan; b) kedudukan atau jabatan yang mempunyai kewenangan tersebut masih (sedang) dipangku atau dimilikinya. ${ }^{33}$ Oleh karena itu, dalam kasus penyelundupan oleh Direktur Garuda sangat relevan.

Badan Pemeriksa Keuangan, mengartikan "menyalahgunakan kewenangan” sebagai perbuatan yang dilakukan dengan cara bertentangan dengan tatalaksana yang semestinya sebagaimana yang diatur dalam peraturan, petunjuk tata kerja, instruksi dinas, dan lain-lain, dan berlawanan atau menyimpang dari maksud tujuan sebenarnya dari pemberian kewenangan, kesempatan atau sarana tersebut. ${ }^{34}$

Sementara Indriyanto Seno Adji, menyatakan "menyalahgunakan kewenangan" dalam hukum pidana, khususnya dalam Tipikor tidak memiliki pengertian yang eksplisitas sifatnya. ${ }^{35}$ Oleh karena itu, dipergunakan pengertian dan kata yang sama yang terdapat atau berasal dari cabang hukum lainnya (Hukum Administrasi Negara) melalui pendekatan ektensif berdasarkan doktrin "De Autonomie van het Materiele Strafrecht" dari H.A. Demeersemen dengan menggunakan pengertian "penyalahgunaan wewenang" dalam Pasal 52 ayat (2) huruf b UU Peradilan TUN, yaitu telah menggunakan wewenangnya untuk tujuan lain dari maksud diberikannya wewenang tersebut atau yang dikenal dengan "detournement de poivoir".

Pengertian-pengertian “menyalahgunakan kewenangan” yang disampaikan oleh para ahli hukum tersebut (khususnya ahli Hukum Pidana),termasuk pengertian yang disampaikan Badan Pemeriksa Keuangan, ketika dicermati ternyata tidak jauh berbeda dengan pengertian "penyalahgunaan wewenang" yang ada dalam konsep Hukum Administrasi Negara. Pengertian "menyalahgunakan kewenangan" ditekankan pada penyimpangan tujuan dari pemberian kewenangan tersebut (penyimpangan asas spesialitas), walapun pada beberapa pengertian ditambahkan dengan unsur lain seperti penyalahgunaan prosedur dan perbuatan yang dilakukan tanpa wewenang/kewenangan. Tetapi unsur penyimpangan tujuan yang selama ini identik dengan pengertian "penyalahgunaan wewenang" dalam Hukum Administrasi Negara selalu disematkan terhadap pengertian "menyalahgunakan kewenangan".

\footnotetext{
${ }^{33}$ Adami Chazawi, Hukum Pidana Materiil dan Formil Korupsi di Indonesia, (Malang: Bayumedia, 2005), 6868.

${ }^{34}$ Adami Chazawi, Hukum Pidana ..., Ibid., hlm. 66.

${ }^{35}$ Putusan MARI Nomor 977K/PID/2004, tanggal 10 Juni 2005.
} 
Perubahan pengertian "penyalahgunaan wewenang" kedalam pengertian "menyalahgunakan kewenangan" selain dalam ranah akademis, juga dilakukan dalam tataran praktis. Praktik peradilan pidana, khususnya Peradilan Tipikor melalui pendekatan ekstensif dengan menggunakan doktrin otonomi hukum pidana telah menggunakan pengertian "penyalahgunaan wewenang" dalam Hukum Administrasi Negara untuk menjelaskan unsur “menyalahgunakan kewenangan” dalam Tipikor dan telah menjadi yurisprudensi.

Doktrin otonomi hukum pidana pertama kali diterima oleh Pengadilan Negeri Jakarta Utara dan dikuatkan oleh Mahkamah Agung RI melalui Putusan Nomor: 1340K/Pid/1992, tanggal 17 Februari 1992, dalam perkara Tipikor yang dikenal dengan perkara "Sertifikat Ekspor", dimana Kabid Ekspor Kanwil IV,Ditjen Bea Cukai Tanjung Priok, Jakarta didakwa melanggar Pasal 1 ayat (1) sub b UU No. 3 Tahun 1971 tentang Pemberantasan Tipikor. ${ }^{36}$ Melalui putusan tersebut Mahkamah Agung RI melakukan penghalusan hukum (rechtsvervijning) terhadap pengertian "menyalahgunakan kewenangan" dalam pasal tersebut, dengan cara mengambil alih pengertian "penyalahgunaan wewenang" yang ada dalam UU Peradilan TUN (Pasal 53 ayat (2) huruf b) ${ }^{37}$ Putusan tersebut kemudian menjadi yurisprudensi dan dijadikan rujukan oleh Hakim Peradilan Pidana dalam pemeriksaan dan pembuktian unsur "menyalahgunakan kewenangan" dalam Tipikor, bahkan setelah Pasal 53 ayat (2) huruf b diubah dan tidak lagi dicantumkan dalam perubahan pertama UU Peradilan TUN. Misalnya saja dalam Putusan Mahkamah Agung RI Nomor: 1485K/Pid.Sus/2013, tanggal 2 Oktober 2013, dengan terdakwa M. Riza Kurniawan, S.E. bin Sutikno. $^{38}$

Pendekatan ekstensif melalui Doktrin Otonomi Hukum Pidana dalam memberikan pengertian unsur "menyalahgunakan kewenangan" dalam pembuktian Tipikor juga masih digunakan setelah lahirnya UU Administrasi Pemerintahan, yaitu dalam Putusan Hakim Pengadilan Tanjung Pinang Nomor: 3/Pid.Sus-TPK/2015/PN.Tpg, tanggal 11 Juni 2015, ketika memutus terdakwa korupsi Yusrizal, A.Ptnh. bin Muhammad Yusuf Bhawan. ${ }^{39}$ Pengertian "penyalahgunaan wewenang" kedalam pengertian "menyalahgunakan kewenangan" juga dapat dilihat dalam kesimpulan penelitian disertasi yang di lakukan oleh

\footnotetext{
${ }^{36}$ Pasal 1 ayat (1) sub b Undang-Undang Nomor 3 Tahun 1971.

${ }^{37}$ Putusan MARI Nomor 979K/PID/2004, tanggal 10 Juni 2005, hlm. 86-88.

${ }^{38}$ Putusan Mahkamah Agung RI Nomor 1485K/Pid.Sus/2013, tanggal 2 Oktober 2013, hlm. 129-132.

${ }^{39}$ Putusan Hakim Pengadilan Tanjung Pinang Nomor 3/Pid.Sus-TPK/2015/PN.Tpg, tanggal 11 Juni 2015, hlm. 94-95.
} 
Budi Parmono dengan judul "Penyalahgunaan Wewenang Dalam Tindak Pidana Korupsi di Indonesia", dimana pada bagian kesimpulan pertama huruf c dinyatakan:

“... sebenarnya kriteria penyalahgunaan wewenang yang berkembang dalam Hukum Administrasi Negara diadopsi kriteria bagian inti delik penyalahgunaan wewenang dalam tindak pidana korupsi melalui doktrin otonomi hukum pidana yang meliputi (1) tindakan-tindakan pejabat tersebut adalah benar ditujukan untuk kepentingan umum, tetapi telah menyimpang dari tujuan apa kewenangan tersebut diberikan oleh undangundang atau peraturan yang lain; (2) kecermatan; dan (3) kepatutan." 40

Bahkan dalam disertasinya tersebut, Budi Darmono tidak menggunakan istilah "menyalahgunakan kewenangan" untuk menyebut unsur Tipikor, tetapi menggunakan istilah "penyalahgunaan wewenang". 41

Berdasarkan uraian tersebut, dapat disimpulkan bahwa secara teoritis dan praktis, konsep "menyalahgunakan kewenangan" dengan konsep "penyalahgunaan wewenang" merupakan hal yang sama, sehingga unsur "menyalahgunakan kewenangan" dalam Tipikor selain berada dalam kewenangan absolut Peradilan Tipikor, juga merupakan kewenangan absolut PeradilanAdministrasi. Kewenangan absolut Peradilan Tipikor secara atributif diberikan UUPengadilan Tipikor yang lebih dahulu diundangkan (pada tanggal 29 Oktober 2009) sebagaimana dinyatakan dalam Pasal 5 dan Pasal 6 undang-undang dimaksud jo. Pasal 3 UU Pemberantasan Tipikor dan sudah berjalan dalam praktik peradilan pidana, khususnya Tipikor.

Sementara itu, kewenangan absolut Peradilan Administrasi secara atributif diberikan oleh UU Administrasi Pemerintahan dengan mengacu pada ketentuan Pasal 21 ayat (1) jo. Pasal 1 angka 18 Jo. Pasal 17 undang-undang tersebut. UUAdministrasi Pemerintahan yang diundangkan kemudian (pada 17 Oktober 2014), secara hierarki memiliki kedudukan yang setara dengan UU Pengadilan Tipikor dan secara substansi mengatur aspek yang sama, namun UU Administrasi Pemerintahan tidak menyinggung apalagi mencabut kewenangan absolut Peradilan Tipikor dalam memeriksa unsur menyalahgunakan kewenangan dalam Tipikor. Padahal, kedua undang-undang tersebut dibentuk dalam rangka pemberantasan korupsi. $^{42}$

\footnotetext{
${ }^{40}$ Budi Parmono: Penyalahgunaan Wewenang Dalam Tindak Pidana Korupsi di Indonesia: Disertasi, Fakultas Hukum UB, Malang, 2011, hlm. 382.

${ }^{41}$ Ibid, hlm. 383

42 Naskah Akademik UU No. 30 Tahun 2014 tentang Administrasi Pemerintahan, hlm. 26.
} 


\section{UNSUR MENYALAHGUNAKAN KEWENANGAN DALAM TIPIKOR SEBAGAI KOMPETENSI ABSOLUT PERADILAN ADMINISTRASI}

Ketika terjadi antinomi hukum karena adanya conflict of norm, maka dapat diselesaikan dengan asas preferensi hukum, yang terdiri dari 3 (tiga) asas, yaitu: lex superior derogat legi inferiori; lex specialis derogat legi generalis; dan lex posteriori derogate legi priori. ${ }^{43}$ Asas hukum lex superior derogat legi inferiori, dapat diterapkan ketika terjadi pertentangan antara peraturan perundang-undangan yang secara hierarki tingkatannya lebih rendah dengan peraturan perundangundangan di atasnya yang lebih tinggi. Menurut asas ini peraturan perundang-undangan dengan tingkatan lebih rendah, keberlakuannya dikesampingkan oleh peraturan perundang-undangan yang tingkatannya lebih tinggi, kecuali substansi yang diatur oleh peraturan perundang-undangan lebih tinggi oleh undang-undang ditetapkan sebagai wewenang peraturan perundang-undangan tingkat lebih rendah.

Berikutnya, asas hukum lex specialis derogat legi generalis, asas ini dapat diaplikasikan ketika terjadi pertentangan antara peraturan perundang-undangan yang bersifat khusus dengan peraturan perundang-undangan yang bersifat umum. Berdasarkan asas ini, aturan hukum yang umum dapat dikesampingkan oleh aturan hukum yang khusus ketika memenuhi beberapa prinsip yaitu: a) aturan-aturan hukum tersebut harus berada dalam lingkungan hukum (rezim) yang sama, misalnya UU Pemberantasan Tipikor dengan KUHP yang sama-sama termasuk rumpun hukum pidana; $b$ ) aturan-aturan hukum tersebut levelnya harus sederajat (undang-undang dengan undang-undang); dan $c$ ) ketentuan-ketentuan lain yang terdapat dalam aturan hukum umum tetap berlaku, kecuali yang diatur khusus dalam aturan hukum khusus tersebut.

Terakhir, asas hukum "lex posteriori derogate legi priori", yang dapat diimplementasikan ketika terjadi pertentangan antara hukum yang dibuat terdahulu dengan hukum yang dibentuk kemudian. Keberlakuan asas ini harus di dasarkan pada terpenuhinya beberapa prinsip berikut: $a$ ) aturan hukum yang baru levelnya harus sederajat atau lebih tinggi dari aturan hukum yang lama; dan $b$ ) aspek yang diatur dalam hukum baru dan hukum lama sama.

Apabila melihat penjelasan dari masing-masing asas tersebut, maka asas preferensi hukum yang dapat diterapkan terhadap conflict of norm dalam ketentuan UU Pengadilan

\footnotetext{
43 Wasis Susetio, Disharmoni Peraturan Perundang-Undangan di Bidang Agraria, Artikel dalam Jurnal Lex Jurnalica, Volume 10 Nomor 3, Desember 2013, hlm. 145.
} 
Tipikor jo. UU Pemberantasan Tipikor dengan ketentuan dalam UU Administrasi Pemerintahan adalah asas hukum "lex posteriori derogate legi priori", karena pertentangan terjadi antara norma yang termuat dalam undang-undang yang telah ada sebelumnya, dengan ketentuan yang terdapat dalam undang-undang yang baru dibentuk. ${ }^{44}$ Selain itu, ketiga undang-undang tersebut kedudukannya dalam hierarki perundang-undangan setara yaitu selevel; undang-undang dan substansi norma yang dipertentangkan aspeknya sama, yaitu mengenai penanganan masalah penyalahgunaan wewenang/menyalahgunakan kewenangan.

Saat dikaji lebih dalam ratio legis pembentukan ketiga peraturan perundangundangan tersebut, terdapat keterkaitan yang sangat erat antara ketiganya, yaitu sama-sama dibentuk dalam upaya pemberantasan Tipikor. UU Pengadilan Tipikor jo. UU Pemberantasan Tipikor yang berada dalam rumpun Hukum Pidana diniatkan untuk memberantas Tipikor melalui sarana penindakan (tindakan represif), sedangkan UU Administrasi Pemerintahan, walaupun berada dalam rumpun Hukum Administrasi Negara dimaksudkan sebagai sarana pemberantasan Tipikor melalui tindakan pencegahan (preventif) dengan pendekatan reformasi birokrasi. Benang merahnya dapat dilihat juga dalam substansi pengaturan penyelenggaraan negara oleh Undang-Undang Nomor 28 Tahun 1999 tentang Penyelenggara Negara Yang Bersih dan Bebas Dari Korupsi, Kolusi dan Nepotisme, yang di dalamnya pure mengatur hubungan antara HAN dan hukum pidana (korupsi). ${ }^{45}$ Berdasarkan asas hukum "lex posteriori derogate legi priori" ini, maka kewenangan untuk memeriksa dan memutus penyalahgunaan kewenangan dalam Tipikor merupakan kompetensi absolut Peradilan Administrasi, karena kompetensi absolut yang dimiliki Peradilan Administrasi diberikan oleh UU Administrasi Pemerintahan yang dibentuk kemudian (post) setelah lahirnya UU Pemberantasan Tipikor dan UU Peradilan Tipikor yang telah ada lebih dulu (prior). ${ }^{46}$

Merujuk pada arah politik hukum pemerintah dalam upaya pemberantasan korupsi, terjadi pergeseran politik hukum pemerintah dalam upaya pemberantasan Tipikor yang dilakukan oleh penyelenggara negara. Saat ini, pemerintah cenderung melakukan penyeimbangan antara upaya pencegahan (preventif) dengan upaya penindakan (represif).

\footnotetext{
44 Sidharta, Penemuan Hukum Melalui Putusan Hakim, Makalah, disampaikan dalam Seminar Nasional Pemerkuatan Pemahaman Hak Asasi Manusia Untuk Hakim Seluruh Indonesia, yang diselenggarakan oleh Komisi Yudisial RI, PUSHAM UII, dan Norsk Senter For Menneskerettigheter Norwegian Centre For Human Rights, Hotel Grand Angkasa Medan, tanggal 2-5 Mei 2011.

45 Yulius: Op.Cit,hlm. 375.

${ }^{46}$ UU No.30 Tahun 2014 tentang Administrasi Pemerintahan.
} 
Romli Atmasasmita, ${ }^{47}$ menyatakan terdapat perubahan arah politik hukum terkait penegakan hukum dalam pemberantasan korupsi di Indonesia, dimana upaya pencegahan korupsi didudukkan sama pentingnya dengan penindakan korupsi. Oleh karena itu, pendekatan yang selama ini digunakan dalam UU Pemberantasan Tipikor, yang menjadikan tindakan represif sebagai "primum remedium" harus ditinjau ulang. Hukum pidana harus dikembalikan kepada khittahnya sebagai senjata pamungkas atau sebagai upaya terakhir yang harus dipergunakan dalam upaya penegakan hukum sesuai dengan asas "ultimum remedium". ${ }^{4}$

Apalagi dalam konteks Hukum Administrasi, keberadaan sanksi pidana menurut Barda Nawawi Arief, ${ }^{49}$ pada hakikatnya merupakan perwujudan dari kebijakan menggunakan hukum pidana sebagai sarana untuk menegakkan/melaksanakan hukum administrasi atau dengan kata lain merupakan bentuk "fungsionalisasi/operasionalisasi/instrumentalisasi hukum pidana di bidang hukum administrasi”, sehingga berada pada tahapan terakhir. Hal ini seperti yang dikemukakan oleh W.F Prins yang dikutip Philipus M. Hadjon, ${ }^{50}$ bahwa hampir setiap peraturan berdasarkan hukum administrasi diakhiri dengan ketentuan pidana sebagai "in cauda venenum" (pada ujungnya).

Berdasarkan kajian atas permasalahan di atas, dapat disimpulkan bahwa kewenangan untuk memeriksa dan memutus unsur "menyalahgunakan kewenangan" karena jabatan dalam Tipikor merupakan kompetensi absolut Peradilan Administrasi, karena konsep "penyalahgunaan wewenang" dalam UU Administrasi Pemerintahan dan konsep "menyalahgunakan kewenangan" dalam UU Pemberantasan Tipikor secara teoritis dan praktis merupakan konsep yang sama. Ketika ada dua hukum (kebijakan legislasi) dengan level sederajat mengatur aspek yang sama, maka berdasarkan asas "lex posteriori derogate legi priori”, hukum yang dibentuk kemudian yang berlaku.

Akar permasalahan timbulnya potensi sengketa kewenangan mengadili antara Peradilan Tipikor dengan Peradilan Administrasi dalam penanganan penyalahgunaan

\footnotetext{
${ }^{47}$ Romli Atmasasmita, Penyalahgunaan Wewenang oleh Penyelenggara Negara: Suatu Catatan Kritis atas UU RI Nomor 30 Tahun 2014 tentang Administrasi Pemerintahan; Dihubungkan dengan UU RI Nomor 20 Tahun 2001 tentang Perubahan atas UU RI Nomor 31 Tahun 1999 tentang Pemberantasan Tindak Pidana Korupsiâ, Makalah, disampaikan dalam Seminar Nasional dalam rangka H.U.T. IKAHI Ke-62 dengan tema UndangUndang Administrasi Pemerintahan, Menguatkan atau Melemahkan Upaya Pemberantasan Korupsi, Hotel Mercure, Ancol Jakarta, tanggal 26 Maret 2015, hlm. 6-7.

48 Suhariyono AR., Perumusan Sanksi Pidana Dalam Pembentukan Peraturan Perundang-Undangan, Artikel dalam Jurnal Perspektif, Volume XVII No. 1 Tahun 2012 Edisi Januari, hlm. 21.

${ }^{49}$ Barda Nawawi Arief, Beberapa Aspek Kebijakan Penegakan dan Pengembangan Hukum Pidana, (Bandung: Citra Aditya, 2005), hlm. 139.

50 Hadjon, Op-cit, 2005, hlm. 245.
} 
kewenangan dalam Tipikor karena adanya pembedaan konsep, teori, dan pengaturan tentang "wewenang" dan "kewenangan" dalam hukum Indonesia. Sementara itu, secara terminologi kedua kata tersebut berasal dari kata yang sama yaitu "wenang" dengan makna yang tidak jauh berbeda, karena keduanya selalu dikonotasikan dengan "hak dan kekuasaan" pejabat publik. Agar tidak terjadi kerancuan pemahaman dan pengaturan mengenai "wewenang" dan "kewenangan", para akademisi hukum, legislatif, dan penegak hukum kiranya perlu melakukan penegasan dan penyamaan persepsi mengenai istilah yang akan digunakan dalam hukum Indonesia dengan memilih salah satu istilah tersebut.

\section{KESIMPULAN}

Penyalahgunaan wewenang oleh pejabat negara, dimungkinkan terjadi karena memang ada peluang untuk melakukan itu. Dengan demikian, penting bagi pemerintah untuk menerapkan asas-asas umum pemerintahan yang baik (secara masif) serta menerapkan fit and profer test agar pengangkatan pejabat negara dapat lebih selektif lagi. Persoalan jauh lebih penting adalah mengetahui sosok (volgeist/karakter) calon pejabat dengan melihat track record perjalanan karirnya, sehingga saat dia terpilih menduduki jabatan tertentu, tidak ibarat membeli kucing dalam karung seperti yang selama ini sering terjadi.

\section{DAFTAR PUSTAKA}

Adji, Indriyanto Seno, Kendala Admnistrative Penal Law Sebagai Tindak Pidana Korupsi dan Pencucian Uang, Makalah Seminar Nasional Penanganan Tindak Pidana Kehutanan dan Tindak Pidana Pencucian Uang dalam Perspektif Tindak Pidana Korupsi, Jakarta: Sasana Pradana Kejaksaan Agung R.I., 16 Juli 2007.

Agustina, Shinta, dkk, Penjelasan Hukum : Sifat Melawan Hukum Dalam Kasus Korupsi, Jakarta: LeIP, 2016.

Arief, Barda Nawawi, Beberapa Aspek Kebijakan Penegakan dan Pengembangan Hukum Pidana, Citra Aditya, Bandung, 2005.

Atmasasmita, Romli, dalam makalah "Penyalahgunaan Wewenang oleh Penyelenggara Negara: disampaikan dalam Seminar Nasional IKAHI, Hotel Mercure, 26 Maret 2015.

Atmasasmita, Romli, Penyalahgunaan Wewenang oleh Penyelenggara Negara: Suatu Catatan Kritis atas UU RI Nomor 30 Tahun 2014 tentang Administrasi Pemerintahan; Dihubungkan dengan UU RI Nomor 20 Tahun 2001 tentang Perubahan atas UU RI 
Nomor 31 Tahun 1999 tentang Pemberantasan Tindak Pidana Korupsiâ, Makalah, disampaikan dalam Seminar Nasional dalam rangka H.U.T. IKAHI Ke-62 dengan tema Undang-Undang Administrasi Pemerintahan, Menguatkan atau Melemahkan Upaya Pemberantasan Korupsi, Hotel Mercure, Ancol Jakarta, tanggal 26 Maret 2015.

BP2B, Kemendikbud, KKBI, Daring, kbbi.web.id/wenang, diakses tanggal 6 September 2020.

Bull, Victoria, Oxford Learnerâ $€^{\mathrm{TM}_{\mathrm{S}}}$ Pocket Dictionary: Fourth Edition, Oxford University Press, Oxford, 2012.

Chazawi, Adami, Hukum Pidana Materiil dan Formil Korupsi di Indonesia, Bayumedia, Malang, 2005.

Disiplin F. Mano. Penyelesaian Penyalahgunaan Wewenang oleh Aparatur Dari Segi Hukum Administrasi Dihubungkan Dengan Tindak Pidana Korupsi Wawasan Yuridika, Volume 2 Nomor 1, Maret 2018.

Faiz, Arfan Muhlizi, Reformulasi Diskresi Dalam Penataan Hukum Administrasi, Artikel dalam Jurnal Rechts Vinding, Volume 1 Nomor 1 Januari-April 2012.

Hadjon, Philipus M., dkk, Hukum Administrasi dan Good Governance, Jakarta: Penerbit Universitas Trisakti, Cetakan Kedua, 2012.

, Peradilan Tata Usaha Negara Dalam Konteks Undang-Undang Nomer 30 Th. 2014, Makalah, disampaikan dalam Colloqium Membedah Undang-Undang Nomor 30 Tahun 2014 tentang Administrasi Pemerintahan, 5 Juni 2015, Garden Palace Surabaya.

Latif, Abdul, Hukum Administrasi Dalam Tindak Pidana Korupsi, Prenada Media Group, Jakarta, 2014.

Marzuki, Laica, Makalah dalam Seminar Ikatan Hakim Indonesia, "UU AP; menguatkan atau memperlemah Pemberantasan Korupsi?” Jakarta, 26 Maret 2014.

Marzuki, Peter Mahmud, Penelitian Hukum, Jakarta: Kencana Prenada Media Group, 2005.

MD, Mahfud Moh. "Keniscayaan Reformasi Hukum: Upaya Menjaga Jati Diri dan Martabat Bangsa", Makalah dalam Konvensi Kampus VI dan Temu Tahunan XII Forum Rektor Indonesia (FRI) di Universitas Tanjungpura Pontianak, 9 Januari 2010.

Moeimam, Susi dan Steinhauer Hein, Kamus Belanda-Indonesia, Gramedia Pustaka, Jakarta, 2005.

Muladi, Proyeksi Hukum Pidana Materiil Indonesia di Masa Datang, Naskah Pidato Pengukuhan Guru Besar dalam Ilmu Hukum pada Fakultas Hukum Universitas Diponegoro Semarang, 1990. 
Nirwanto, Andhi, Dikotomi Terminologi Keuangan Negara dalam Perspektif Tindak Pidana Korupsi, Semarang: Aneka Ilmu, Cetakan Pertama, 2014.

Panjaitan. Penyelesaian Penyalahgunaan Wewenang yang Menimbulkan Kerugian Negara Menurut Hukum Administrasi Pemerintahan, Jurnal IU, Sekolah Tinggi Hukum Bandung, Bandung, Vol 24 , No 3, Juli, 2017.

Parmono, Budi, Penyalahgunaan Wewenang Dalam Tindak Pidana Korupsi di Indonesia: Disertasi, Fakultas Hukum UB, Malang, 2011.

Pengurus Pusat Ikatan Hakim Indonesia (IKHI), Term of Reference (TOR), Seminar nasional Ündang-Undang Administrasi Pemerintahan: Menguatkan atau Melemahkan Upaya Pemberantasan Korupsi”, Jakarta, 11 Februari 2015.

Permana, Tri Cahya Indra, Hak Permohonan Pejabat/Badan Atas Dugaan Penyalahgunaan Wewenang: Bunga Rampai Peradilan Administrasi Kontemporer, Editor Subur, dkk., Genta Press, Yogyakarta, 2014.

Poerwadarminta, WJS, Kamus Besar Bahasa Indonesia: Jakarta, Balai Pustaka, 1976.

Sidharta, B. Arief, "Pembentukan Hukum di Indonesia", Makalah disampaikan dalam Rapat Kerja Panitia Khusus DPR RI Rancangan Undang-Undang Tentang Pembentukan Peraturan Perundang-undangan, Rapat Dengar Pendapat Umum dengan para Pakar, Rabu, 26 Januari 2011.

Sidharta, Penemuan Hukum Melalui Putusan Hakim, Makalah, disampaikan dalam Seminar Nasional Pemerkuatan Pemahaman Hak Asasi Manusia Untuk Hakim Seluruh Indonesia, yang diselenggarakan oleh Komisi Yudisial RI, PUSHAM UII, dan Norsk Senter For Menneskerettigheter Norwegian Centre For Human Rights, Hotel Grand Angkasa Medan, tanggal 2-5 Mei 2011.

Suandi, I Wayan, Penggunaan Wewenang Paksaan Pemerintah dalam Penyelenggaraan Pemerintahan di Propinsi Bali; Surabaya: Disertasi, Universitas Airlangga, 2003.

Suhariyono AR., Perumusan Sanksi Pidana Dalam Pembentukan Peraturan PerundangUndangan, Artikel dalam Jurnal Perspektif, Volume XVII No. 1 Tahun 2012 Edisi Januari.

Susetio, Wasis, Disharmoni Peraturan Perundang-Undangan di Bidang Agraria, Artikel dalam Jurnal Lex Jurnalica, Volume 10 Nomor 3, Desember 2013.

Wiyono, R., Pembahasan Undang-Undang Pemberantasan Tindak Pidana Korupsi, Edisi Kedua, Sinar Grafika, Jakarta, 2012.

Yulius, Perkembangan Pemikiran dan Pengaturan Penyalahgunaan Wewenang di Indonesia (Tinjauan Singkat Dari Perspektif Hukum Administrasi Negara Pasca Berlakunya Undang-Undang Nomor 30 Tahun 2014), Artikel dalam Jurnal Hukum dan 
Peradilan, Badan Penelitian dan Pengembangan Hukum dan Peradilan Mahkamah Agung RI, Volume 04 Nomor 3 November 2015.

Yuridika, Nomor 6 Tahun IX, "Pengkajian Ilmu Hukum Dogmatik (normatif)", NopemberDesember 1994.

Undang-Undang Nomor 30 Tahun 2014 tentang Administrasi Pemerintahan

Undang-Undang Nomor 5 Tahun 1986 tentang Peradilan Tata Usaha Negara 